\title{
Light Hydrocarbons in the Surface Water of the Mid-Atlantic
}

\author{
C. PLASS, R. KOPPMANN, and J. RUDOLPH
}

\begin{abstract}
During a cruise of $R V$ Polarstern over the Atlantic in September/October 1988, $\mathrm{C}_{2}-\mathrm{C}_{4}$ hydrocarbons were measured in surface sea water. The ship passed through three different ocean regions divided by divergences at $8^{\circ} \mathrm{N}$ and $3^{\circ} \mathrm{S}$. Hydrocarbon concentrations differed considerably in these regions. The highest values were obtained for ethene with mean concentrations of $246 \mathrm{pMol} / 1$ between $35^{\circ} \mathrm{N}$ and $8^{\circ} \mathrm{N}, 165 \mathrm{pMol} / 1$ between $8^{\circ} \mathrm{N}$ and $3^{\circ} \mathrm{S}$, and $63 \mathrm{pMol} / 1$ between $3^{\circ} \mathrm{S}$ and $30^{\circ} \mathrm{S}$. Low values were found for $i$ - and $n$-butane and acetylene between $32 \mathrm{pMol} / 1$ and $1 \mathrm{pMol} / 1$. The alkene concentrations were in general higher than the concentrations of their saturated homologs. Concentrations decreased with increasing carbon numbers. The various alkenes were well correlated with one another as were the various alkanes. Oceanic emission rates of the light hydrocarbons were calculated from their sea water concentrations using an ocean atmosphere exchange model. The averaged fluxes ranged from about $10^{8}$ molec $\mathrm{cm}^{-2} \mathrm{~s}^{-1}$ for the alkenes and ethane to less than $10^{7}$ molec $\mathrm{cm}^{-2} \mathrm{~s}^{-1}$ for the $C_{4}$ alkanes. Acetylene emissions were below $3 \times 10^{\prime \prime}$ molec $\mathrm{cm}^{-2} \mathrm{~s}^{-1}$. Based upon these rates budget estimates of NMHC in the ocean surface layer were made with a simple model considering production and destruction processes in the water. The emissions to the atmosphere appear to be the dominant loss process between $35^{\circ} \mathrm{N}$ and $8^{\circ} \mathrm{N}$, whereas destruction in the water seems to be dominant in the latitude ranges $8^{\circ} \mathrm{N}-3^{\circ} \mathrm{S}$ and $3^{\circ} \mathrm{S}-30^{\circ} \mathrm{S}$.
\end{abstract}

Key words: Hydrocarbons, sea-water emissions, hydrocarbon budgets.

\section{Introduction}

Oceanic emissions of nonmethane hydrocarbons (NMHC) have a considerable impact on the atmospheric hydrocarbon abundances in the remote marine troposphere (Rudolph and Ehhalt, 1981; Bonsang et al., 1988; Penkett, 1982). The emission rates were derived indirectly from atmospheric budget calculations (Penkett, 1982) or were estimated from sea-air exchange models and sea-water concentrations (Rudolph and Ehhalt, 1981). Bonsang and Lambert (1985) used a correlation between propane with the continental tracer ${ }^{222} \mathrm{Rn}$ in the marine atmosphere to estimate the oceanic source of propane. Bonsang et al. (1988) deduced the oceanic emissions of several NMHC from their concentrations in sea water relative to propane. Generally, estimates of oceanic hydrocarbon emission rates are still rare and based only on data from restricted areas. Measurements of light hydrocarbons in sea water were first reported by Swinnerton and Linnenbom (1967), Linnenbom and Swinnerton (1970), Lamontagne et al. (1974), and Swinnerton and Lamon- 
tagne (1974). Their experimental method was adopted by several other groups (Frank et al., 1970; Brooks and Sackett, 1973; Macdonald, 1976). Based on their atmospheric NMHC measurements and previously published NMHC concentrations in ocean water (Swinnerton and Lamontagne, 1974), Rudolph and Ehhalt (1981) suggested that the ocean surface is supersaturated in hydrocarbons relative to the atmosphere. To our knowledge, the only simultaneous measurements of NMHC in sea water and the atmosphere were published by Bonsang et al. (1988). Their results showed a high supersaturation of hydrocarbons in sea water relative to the atmosphere. Still, our quantitative knowledge about the budgets of $C_{2}-C_{4}$ hydrocarbons in sea water and hydrocarbon emissions into the atmosphere is very limited.

This paper presents measurements of dissolved $\mathrm{C}_{2}-\mathrm{C}_{4}$ hydrocarbons in the surface water of the mid-Atlantic. They were made simultaneously with atmospheric measurements of NMHC and thus allow to calculate the oceanic emissions into the atmosphere. Based on the sea-water concentrations and these emission rates, the production and the loss rates of hydrocarbons in sea water are estimated.

\section{Experimental}

The NMHC concentrations in sea water were measured by gas chromatography during Polarstern cruise ANT VII/1 between $35^{\circ} \mathrm{N}$ and $30^{\circ} \mathrm{S}$. Details of the cruise track from Bremerhaven (Germany) to Rio Grande do Sul (Brazil) are given by Platt et al. (1992). Sixty-five samples were taken from an inlet at $11 \mathrm{~m}$ depth, about $0.5 \mathrm{~m}$ below the hull of the ship. The water was continuously pumped through a stainless steel pipe system into the laboratory. The samples were passed through a glass microfibre filter (Whatman GF/C, pore size $1.2 \mu \mathrm{m}$ ) and volumes of $870 \mathrm{ml}$ were transferred to a stripping chamber similar to that described by Swinnerton and Lamontagne (1967). The volatile hydrocarbons were stripped from the water sample for $30 \mathrm{~min}$ with ultrapure Helium at a flowrate of $100 \mathrm{~cm}^{3} / \mathrm{min}$. The stripping efficiency of the $\mathrm{C}_{2}-\mathrm{C}_{4}$ hydrocarbons exceeded $90 \%$ except for acetylene with $80 \pm 9 \%$.

The hydrocarbons were cryogenically preconcentrated from the purge gas and analyzed by gas chromatography. Details of the technique are described elsewhere (Koppmann et al., 1992; Rudolph et al., 1990). For quantification, an air sample of known composition was preconcentrated and analyzed by the same procedure. The sea-water concentrations were calculated by comparison of the peak heights from sample and reference air assuming $100 \%$ stripping efficiency. Acetylene concentrations were corrected for the stripping efficiency of only $80 \%$. The lower limit of detection for the $\mathrm{C}_{2}-\mathrm{C}_{4}$ hydrocarbons was $1 \mathrm{pMol}\left(10^{-12} \mathrm{Mol}\right)$ to $2.5 \mathrm{pMol}$ per liter of sea water. The reproducibility was $20 \%$ for ethane, $25 \%$ for 1 -butene, and better than $10 \%$ for the other hydrocarbons. The accuracy of the method was about $20 \%$ to $25 \%$ for the $\mathrm{C}_{2}$ and $\mathrm{C}_{3}$, and $30-40 \%$ for $\mathrm{C}_{4}$ hydrocarbons mainly due to uncertainties in the calibration. 


\section{Results and Discussion}

In the equatorial Atlantic current system, there are two divergences associated with upwelling water (Sverdrup et al., 1942). We located these divergences at $8^{\circ} \mathrm{N}$ and $3^{\circ} \mathrm{S}$ by minima of the sea-surface temperature. We assumed that these divergences divide the equatorial Atlantic into different regions: north of $8^{\circ} \mathrm{N}$, between $8^{\circ} \mathrm{N}$ and $3^{\circ} \mathrm{S}$, and south of $3^{\circ} \mathrm{S}$. We will discuss our results with respect to these individual latitude ranges. In all these regions, the primary productivity was low. Estimates of the plankton biomass by Kuosa (private communication) yielded roughly $20 \mu \mathrm{g} \mathrm{C} / 1$. Just around the upwelling zones slightly enhanced plankton concentrations were observed.

\subsection{The Concentrations of Hydrocarbons in Sea Water}

Figure 1(a) shows the latitudinal distribution of ethene and propene in sea water. Ethene, propene and 1-butene (not shown) concentrations followed the same latitudinal pattern. However, the levels of the latter two were lower by factors of 2 and 3.5 , respectively. The alkanes showed a different latitudinal pattern compared to the alkenes. The distributions of propane and $n$-butane (not shown) were similar to that of ethane (Figure 1(b)), but lower by factors 3.5 and 6.2 , respectively.

The main features of the latitudinal distributions are as follows. In the range between $35^{\circ} \mathrm{N}$ and $8^{\circ} \mathrm{N}$, the alkene and alkane concentrations showed on the average the highest concentrations, e.g. for ethene $246 \mathrm{pMol} / \mathrm{l}$ and for ethane 221 $\mathrm{pMol} / \mathrm{l}$ (cf. Table I), but it should be noted that the largest variations were observed in this range. For example, peak values were $546 \mathrm{pMol} / 1$ for ethene and 639 $\mathrm{pMol} / 1$ for ethane at $30^{\circ} \mathrm{N}$, the highest observed throughout the whole cruise, and minima were below $90 \mathrm{pMol} / 1$ at $12^{\circ} \mathrm{N}$ for ethene and ethane. In vicinity of the equatorial upwelling, between $8^{\circ} \mathrm{N}$ and $3^{\circ} \mathrm{S}$, the alkene concentrations exhibited a broad relative maximum with an average of $165 \mathrm{pMol} / 1$ for ethene. No enhancement was seen in the ethane distribution. South of $3^{\circ} \mathrm{S}$, the alkene and alkane concentrations in sea water were very low and relatively constant. The concentrations decreased to 40 and $5 \mathrm{pMol} / \mathrm{l}$ at $30^{\circ} \mathrm{S}$ for ethene and ethane, respectively. The alkenes generally showed higher concentrations than their saturated homologs. This was more pronounced between $8^{\circ} \mathrm{N}$ and $30^{\circ} \mathrm{S}$ than between $35^{\circ} \mathrm{N}$ and $8^{\circ} \mathrm{N}$. The latitudinal distribution of acetylene (Figure 3(a)) showed fairly constant concentrations on a low level. The average concentrations for the different latitude ranges were $6.6 \mathrm{pMol} / 1$ at $35^{\circ} \mathrm{N}$ to $8^{\circ} \mathrm{N}, 4.7 \mathrm{pMol} / 1$ at $8^{\circ} \mathrm{N}$ to $3^{\circ} \mathrm{S}$, and $4.1 \mathrm{pMol} / 1$ at $3^{\circ} \mathrm{S}$ to $30^{\circ} \mathrm{S}$ (cf. Table I). The peak concentration of $15 \mathrm{pMol} / 1$ was found at $30^{\circ} \mathrm{N}$.

We can compare our data with those from other studies (Table I). Since most of the available data are from different regions and seasons, this comparison can only provide an idea of the magnitude, scatter and relative abundance of the various NMHC. Only surface water concentrations are compared down to a maximum 

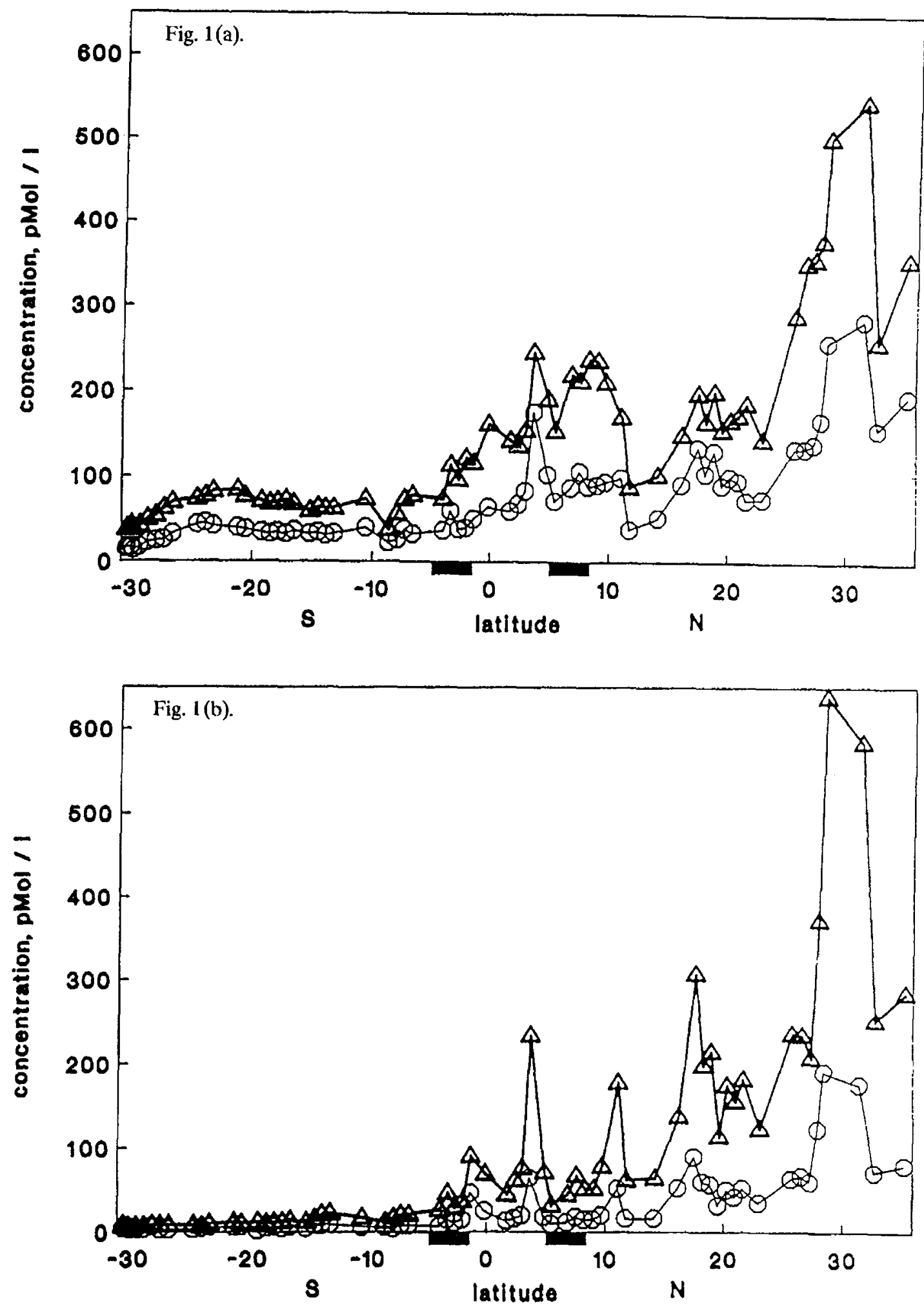

Fig. 1. Latitudinal distribution of hydrocarbon concentrations in sea water: (a) ethene (triangles) and propene (circles), (b) ethane (triangles) and propane (circles). The black bars indicate the upwelling
regions. 
Table I. The mean sea water concentrations of $C_{2}-C_{4}$ hydrocarbons from our data for different latitude ranges compared to results from other authors. The concentrations are given in $\mathrm{pMol} / \mathrm{l}$ with the standard deviations in parentheses. The standard deviations were calculated from the data given in the references

\begin{tabular}{|c|c|c|c|c|c|c|c|c|}
\hline \multirow[t]{2}{*}{ Compound } & \multicolumn{4}{|l|}{ Our data } & \multirow{2}{*}{$\begin{array}{l}\text { Swinnerton } \\
\text { et al. (1974) }\end{array}$} & \multirow{2}{*}{$\begin{array}{l}\text { Brooks and } \\
\text { Sackett } \\
(1974)^{a}\end{array}$} & \multirow{2}{*}{$\begin{array}{l}\text { MacDonald } \\
(1976)\end{array}$} & \multirow{2}{*}{$\begin{array}{l}\text { Bonsang } \\
\text { et al. } \\
(1988)\end{array}$} \\
\hline & $35^{\circ} \mathrm{N}-30^{\circ} \mathrm{S}$ & $35^{\circ} \mathrm{N}-8^{\circ} \mathrm{N}$ & $8^{\circ} \mathrm{N}-3^{\circ} \mathrm{S}$ & $3^{\circ} \mathrm{S}-30^{\circ} \mathrm{S}$ & & & & \\
\hline Ethene & $147(110)$ & $246(123)$ & $165(49)$ & $63(14)$ & \multirow{3}{*}{$\begin{array}{l}214(112) \\
63(40)\end{array}$} & \multirow[t]{3}{*}{$134 \mathrm{pMol} / /$} & \multirow{3}{*}{$\begin{array}{l}54(28) \\
50(26)\end{array}$} & $677(506)$ \\
\hline Propene & $73(57)$ & $125(61)$ & $78(35)$ & $31(9)$ & & & & $326(217)$ \\
\hline 1-Butene & $42(30)$ & $71(30)$ & $44(16)$ & $18(7)$ & & & & $91(68)$ \\
\hline Ethane & $96(129)$ & $221(151)$ & $69(51)$ & $13(6)$ & $22(9)$ & $134 \mathrm{pMol} / 1$ & $37(16)$ & $191(170)$ \\
\hline Propane & $29(38)$ & $65(46)$ & $21(16)$ & $5.8(1.8)$ & $15(15)$ & 45 & $13(9)$ & $110(87)$ \\
\hline$i$-Butane & $2.7(3.1)$ & $4.9(4.0)$ & $2.9(1.4)$ & $1.2(0.9)$ & \multirow{2}{*}{$2.2^{11}$} & \multirow{2}{*}{$4.5^{\mathrm{h}}$} & \multirow{2}{*}{$3.6(2.5)^{\mathrm{b}}$} & $32(27)$ \\
\hline$n$-Butane & $15(21)$ & $32(28)$ & $10.4(8.3)$ & $2.8(1.4)$ & & & & $52(41)$ \\
\hline Acetylene & $5.1(2.9)$ & $6.6(2.9)$ & $4.7(1.0)$ & $4.1(1.3)$ & & & & \\
\hline
\end{tabular}

a Brooks and Sackett (1974) did not report data tables for their open ocean concentrations; thus no standard deviations could be calculated. For ethene and ethane they only gave the sum of $134 \mathrm{pMol} / 1$.

'For the butanes only sums of both isomers were reported. 
sampling depth of $14 \mathrm{~m}$. In order to allow for an estimate of the scatter of the data, the standard deviations were calculated and are given in parentheses. Swinnerton and Lamontagne reported 'average baseline concentrations' for the open ocean. They made 452 measurements of light hydrocarbons mainly in the Gulf of Mexico, Caribbean Sea, Pacific, tropical North-West and the North Atlantic between 1967 and 1973. Brooks and Sackett (1974) published open ocean concentrations for the sum of ethene and ethane, for propane and the butanes obtained in the Gulf of Mexico and the Caribbean Sea. Macdonald (1976) measured $C_{1}-C_{4}$ hydrocarbons in the shelf region of the Southern Beaufort Sea, where seasonal ice-coverage occurs. Averages and standard deviation of his data from August 1974 and August 1975 are shown in Table I. The averages of hydrocarbon sea-water concentrations by Bonsang et al. (1988) are in general higher than the values of other authors. Their data were obtained in the ocean region between Madagascar and Somalia in April 1985. This region includes coastal upwelling zones. Thus, their elevated levels are possibly due to enhanced biological activity which might result in elevated concentrations of volatile hydrocarbons in sea water. Their average concentrations are comparable to our maximum concentrations at $30^{\circ} \mathrm{N}$ (cf. Figure 1 and Table I) or to measurements obtained close to coast lines and harbours reported by Swinnerton and Lamontagne (1974). Comparing all the average concentrations, the range of individual alkenes is about an order of magnitude, whereas alkanes differ up to a factor of 25 . But in addition to different average values individual NMHC concentrations vary considerably within each dataset. The standard deviations in Table I often exceed $50 \%$ of the average concentration and indicate highly inhomogeneous distributions of dissolved NMHC in sea water, e.g. the concentrations given by Bonsang et al. (1988) vary by an order of magnitude. Nevertheless, two general features can be seen: alkenes exceed the concentrations of their saturated homologs and the concentrations decrease with increasing carbon number per compound.

A more detailed view to the relative patterns of hydrocarbons is interesting. Similar geographical structures of different alkenes and of different alkanes have already been indicated in Figures 1 (a) and (b). Linear correlations of our data of all three ocean regions show proportionality between different alkenes (Figure 2(a)) and between different alkanes (Figure 2(b)) with regression coefficients better than 0.95. Also, Bonsang et al. (1988) observed fairly constant ratios between the concentrations of light hydrocarbons. However, although our ethene-propene ratio of $2.1 \pm 0.4$ is quite close to the ratio of Bonsang et al. (1988) of $2.1 \pm 0.6$, other ratios like their ethane- $n$-butane ratio of $3.5 \pm 0.5$ differ from our value of $6.2 \pm 0.2$. From the data of Swinnerton and Lamontagne (1974), ethene-propene ratios of $3.6 \pm 1.5$ can be derived. This is roughly $50 \%$ larger than our value and indicates a considerable relative variability of these most abundant alkenes. Between alkenes and alkanes (Figure 2(c)) our data show reasonable correlations with coefficients between 0.80 and 0.94 . A common feature in the alkene-alkane correlations is the fact that the regression curve intercepts the alkene axis at significantly positive 

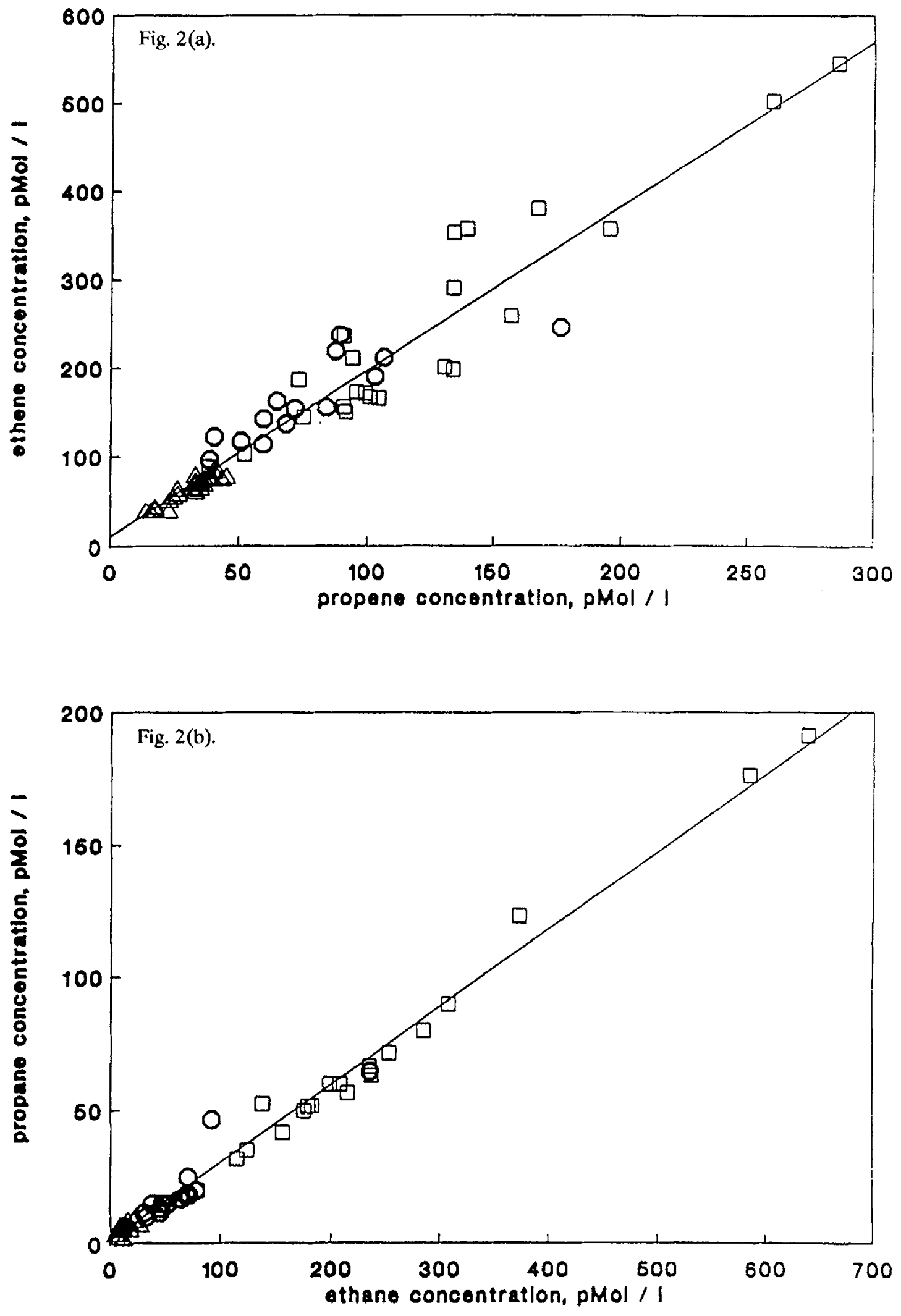


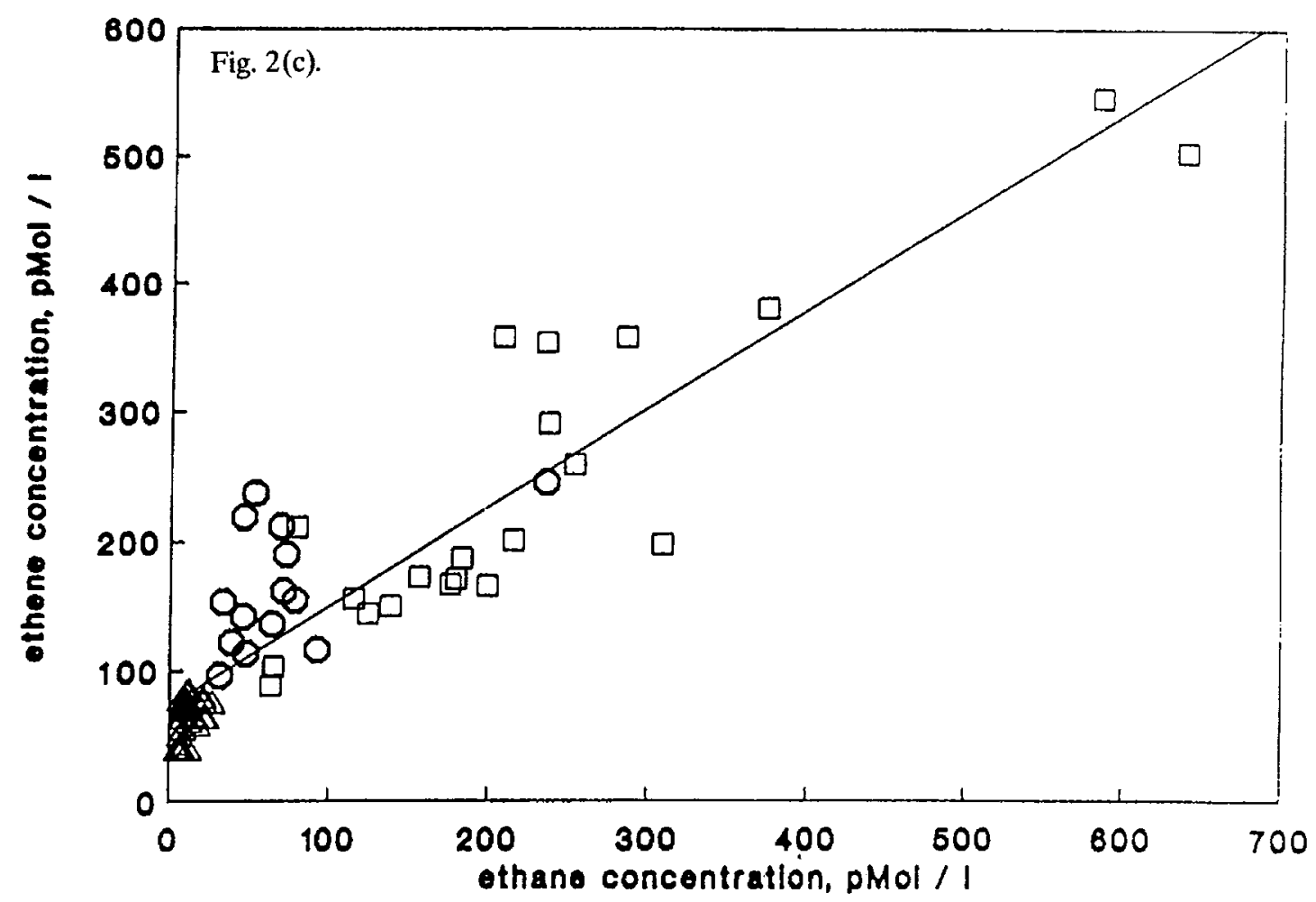

Fig. 2. Correlations between the sea water concentrations of (a) ethene and propene, (b) propane and ethane, (c) ethene and ethane. The latitude ranges are indicated by symbols: $35^{\circ} \mathrm{N}-8^{\circ} \mathrm{N}$ squares, $8^{\circ} \mathrm{N}-3^{\circ} \mathrm{S}$ circles, and $3^{\circ} \mathrm{S}-30^{\circ} \mathrm{S}$ triangles.

values, e.g. the ethene axis intercept in the ethene-ethane correlation is $73 \pm 8$ $\mathrm{pMol} / \mathrm{l}$. This is in contrast to alkene-alkene and alkane-alkane correlations, where no significant axis intercepts were obtained. This feature points towards different production or destruction mechanisms for alkenes and alkanes. The ethene-ethane ratios in our data were not constant and increased by a factor of 5 from $35^{\circ} \mathrm{N}-8^{\circ} \mathrm{N}$ (squares) to $3^{\circ} \mathrm{S}-30^{\circ} \mathrm{S}$ (triangles). It should be noted that the ethene-ethane correlation (Figure 2(c)) is mainly determined by the data from $35^{\circ} \mathrm{N}-8^{\circ} \mathrm{N}$ which cover the widest concentration range. Furthermore, the data from $8^{\circ} \mathrm{N}-3^{\circ} \mathrm{S}$ and $3^{\circ} \mathrm{S}-$ $30^{\circ} \mathrm{S}$ form somewhat separate clusters which do not really fit into the linear correlation. Bonsang et al. (1988) reported that the relative composition of NMHC in sea water is quite constant within a variability of $30-60 \%$. Since, generally, their concentrations were much higher than our values, their data could not reveal relatively small axis intercepts.

\subsection{Oceanic NMHC Emissions}

Based on Henry's Law Constants (McAuliffe, 1966; Wilhelm et al., 1977) and the simultaneously measured atmospheric hydrocarbon concentrations (Koppmann $e t$ al., 1992) the ocean proved to be supersaturated by factors between 20 and 1000 
for all NMHC except acetylene. Thus, the ocean is a source for atmospheric NMHC. For acetylene the situation was different, since the sea-water concentrations were close to equilibrium with atmospheric concentrations (cf. Figure 3(a)). Near $30^{\circ} \mathrm{N}$ and in the ranges $10^{\circ} \mathrm{N}$ to the equator and $10^{\circ} \mathrm{S}$ to $25^{\circ} \mathrm{S}$, the ocean was supersaturated in acetylene with respect to the atmosphere; near $5^{\circ} \mathrm{S}$ and $15^{\circ} \mathrm{N}$ the situation was reversed. Thus, the direction of acetylene fluxes between the ocean and the atmosphere changed regionally. The fluxes $(F)$ can be derived from the ocean-atmosphere exchange model by Liss and Merlivat (1986):

$$
F=k_{w}\left(c_{w}-c_{u} / H\right),
$$

where $k_{w^{\prime}}=$ transfer velocity,

$c_{w^{\prime}}=$ hydrocarbon concentration in sea water,

$c_{a}=$ hydrocarbon concentration in atmosphere,

$H=$ dimensionless Henry's Law Constant.

For all NMHC except acetylene, $c_{a} / H$ is small compared to $c_{w}$ and Equation (1) can be simplified to

$$
F=k_{w^{\prime}} c_{w^{*}}
$$

The transfer velocity $k_{w}$ was calculated from wind velocities and the Schmidt number for $\mathrm{CO}_{2}$ (Jähne, 1980) at the actual sea-water temperatures. The calculation of

\section{acetylene concentration, pMol/I}

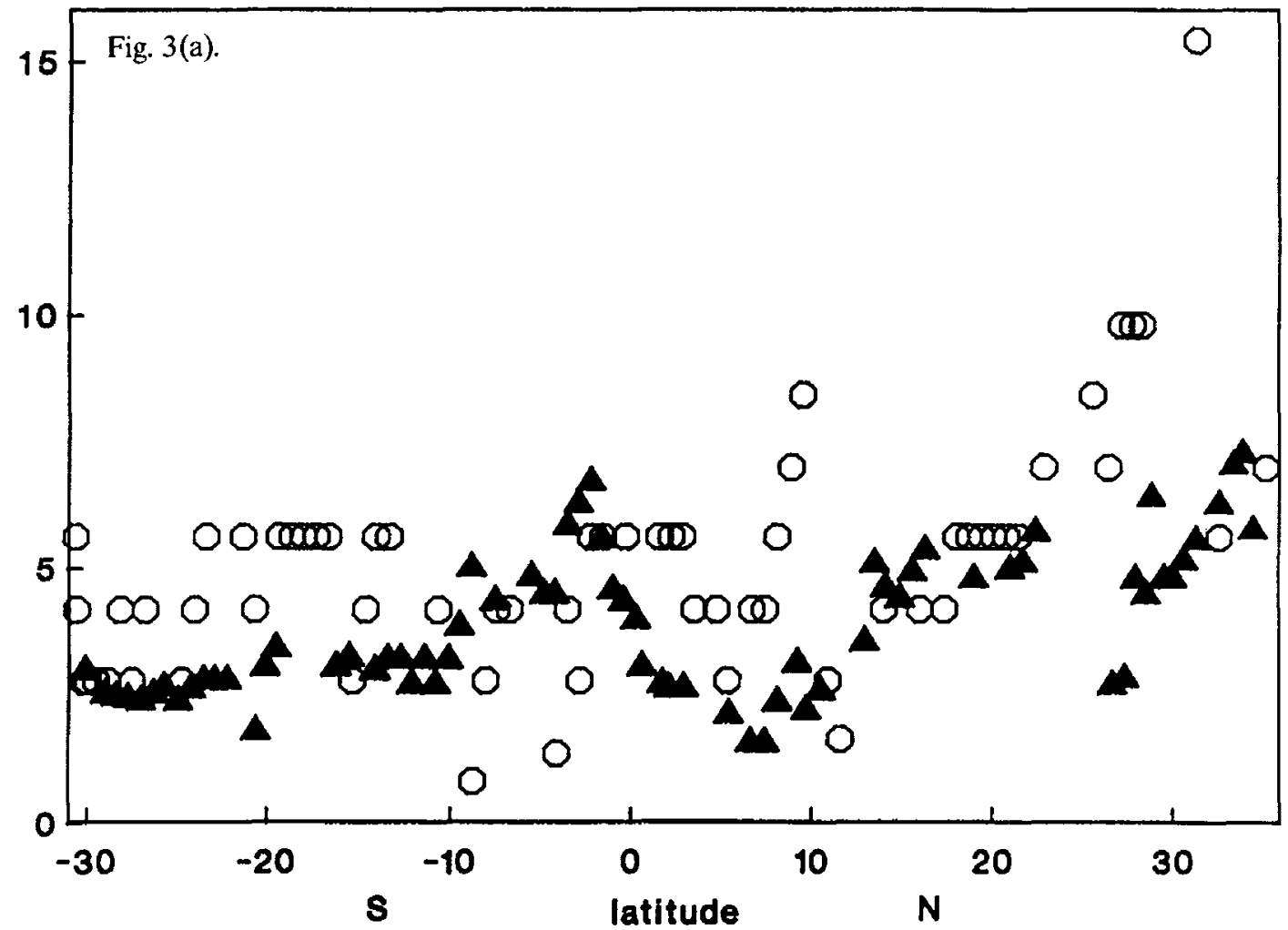




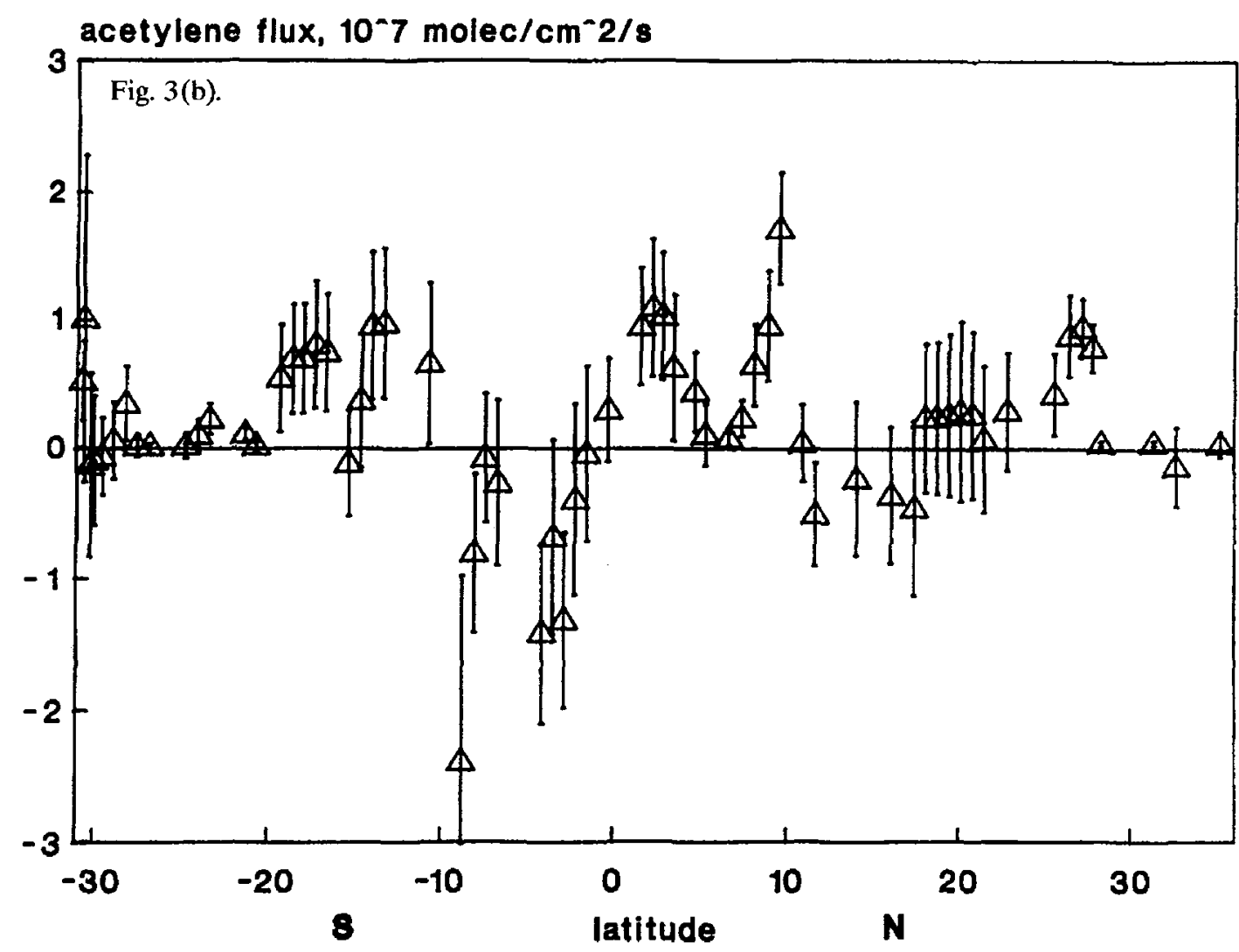

Fig. 3. (a) Acetylene concentration in sea water (circles). Also shown are the equilibrium concentrations calculated from the atmospheric acetylene concentration devided by the dimensionless Henry's Law constant (triangles). (b) Acetylene fluxes across the air sea interface; positive values represent ocean to atmosphere fluxes.

$k_{u^{\prime}}$ for the various hydrocarbons from the Schmidt number of $\mathrm{CO}_{2}$ is valid within better than $10 \%$ for the $C_{2}$ hydrocarbons. For convenience, we used the same transfer velocity for all NMHC. This overestimates the emissions of $\mathrm{C}_{4}$ hydrocarbons by up to $25 \%$. Considering the accuracy of the $\mathrm{C}_{4}$ hydrocarbon measurements and all other uncertainties of transfer velocity estimates, this simplification is justified. The emission rates are listed in Table II. As a consequence of Equation (2), the emission pattern reflects the concentration pattern (Table I). Owing to generally higher transfer velocities in the Southern Hemisphere (cf. Table III) the differences between the regions $35^{\circ} \mathrm{N}$ to $8^{\circ} \mathrm{N}$ and $3^{\circ} \mathrm{S}$ to $30^{\circ} \mathrm{S}$ decrease. The light alkenes and ethane showed the highest emission rates with overall averages exceeding $10^{8}$ molec $\mathrm{cm}^{-2} \mathrm{~s}^{-1}$ and ranged between $0.4 \times 10^{8}$ and $5 \times 10^{8}$ molec $\mathrm{cm}^{-2} \mathrm{~s}^{-1}$ within the three regions. The emissions of the other alkanes averaged over all data were below $10^{8}$ molec $\mathrm{cm}^{-2} \mathrm{~s}^{-1}$, for the different latitude ranges they varied from $1.2 \times 10^{8}$ molec cm$~_{-2} \mathrm{~s}^{-1}$ (propane, $35^{\circ} \mathrm{N}-8^{\circ} \mathrm{N}$ ) to $3 \times 10^{6} \mathrm{molec} \mathrm{cm}^{-2} \mathrm{~s}^{-1}$ (i-butane, $3^{\circ} \mathrm{S}-30^{\circ} \mathrm{S}$ ).

Only for acetylene, occasionally fluxes from the atmosphere into the ocean were calculated. Neither the acetylene uptake nor the emission (Figure 3(b)) exceeded 
Table II. Emission rates of $\mathrm{C}_{2}-\mathrm{C}_{4}$ hydrocarbons in $10^{8}$ molec $\mathrm{cm}^{-2} \mathrm{~s}^{-1}$ with their standard deviation in parentheses, averaged for all measurements and for the three latitude ranges (see text)

\begin{tabular}{lllll}
\hline & $35^{\circ} \mathrm{N}-30^{\circ} \mathrm{S}$ & $35^{\circ} \mathrm{N}-8^{\circ} \mathrm{N}$ & $8^{\circ} \mathrm{N}-3^{\circ} \mathrm{S}$ & $3^{\circ} \mathrm{S}-30^{\circ} \mathrm{S}$ \\
\hline Ethene & $3.4(2.3)$ & $4.9(2.2)$ & $4.5(2.1)$ & $1.7(1.0)$ \\
$\begin{array}{l}\text { Propene } \\
\text { l-Butene }\end{array}$ & $1.7(1.4)$ & $2.6(1.4)$ & $2.2(1.6)$ & $0.85(0.50)$ \\
Ethane & $1.0(0.8)$ & $1.5(0.7)$ & $1.2(0.8)$ & $0.50(0.32)$ \\
$\begin{array}{l}\text { Propane } \\
\text { i-Butane }\end{array}$ & $2.1(2.6)$ & $4.3(2.9)$ & $2.2(2.3)$ & $0.41(0.33)$ \\
$n$-Butane & $0.65(0.75)$ & $1.2(0.8)$ & $0.70(0.70)$ & $0.17(0.12)$ \\
& $0.07(0.06)$ & $0.09(0.06)$ & $0.09(0.05)$ & $0.03(0.02)$ \\
Acetylene & $0.32(0.37)$ & $0.60(0.39)$ & $0.35(0.37)$ & $0.09(0.09)$ \\
\hline
\end{tabular}

Table III. Fit parameters according to equation (5) for $\mathrm{C}_{2}-\mathrm{C}_{4}$ alkene and $n$-alkane sea water concentrations with the standard deviation in parentheses

\begin{tabular}{|c|c|c|c|c|c|}
\hline & Latitude range & $\begin{array}{l}\text { Production } \\
\text { rate } P \\
\left(10^{8} \text { molec }\right. \\
\left.\mathrm{cm}^{-2} \mathrm{~s}^{-1}\right)\end{array}$ & $\begin{array}{l}\text { Destruction } \\
\text { rate constant } \\
D_{0}\left(\mathrm{~cm} \mathrm{~h}^{-1}\right)\end{array}$ & $\begin{array}{l}\text { Transfer } \\
\text { velocity } k_{\mathrm{n}} \\
\left(\mathrm{cm} \mathrm{h}^{-1}\right)\end{array}$ & $\begin{array}{l}\text { Regr. } \\
\text { coeff. } \\
R\end{array}$ \\
\hline \multirow[t]{3}{*}{ Ethene } & $35^{\circ} \mathrm{N}-8^{\circ} \mathrm{N}$ & $8.8(1.0)$ & $9.7(1.6)$ & $15(8)$ & 0.98 \\
\hline & $8^{\circ} \mathrm{N}-3^{\circ} \mathrm{S}$ & $14(5.0)$ & $34(18)$ & $17(8)$ & 0.98 \\
\hline & $3^{\circ} \mathrm{S}-30^{\circ} \mathrm{S}$ & $11(4.0)$ & $87(38)$ & $18(12)$ & 0.98 \\
\hline \multirow[t]{3}{*}{ Propene } & $35^{\circ} \mathrm{N}-8^{\circ} \mathrm{N}$ & $4.3(0.5)$ & $9.3(1.5)$ & $15(8)$ & 0.98 \\
\hline & $8^{\circ} \mathrm{N}-3^{\circ} \mathrm{S}$ & $11(13)$ & $64(94)$ & $17(8)$ & 0.92 \\
\hline & $3^{\circ} \mathrm{S}-30^{\circ} \mathrm{S}$ & $4.8(2.2)$ & $78(41)$ & $18(12)$ & 0.97 \\
\hline \multirow[t]{3}{*}{ 1-Butene } & $35^{\circ} \mathrm{N}-8^{\circ} \mathrm{N}$ & $2.8(0.3)$ & $11.6(1.8)$ & $15(8)$ & 0.97 \\
\hline & $8^{\circ} \mathrm{N}-3^{\circ} \mathrm{S}$ & $6.8(7.8)$ & $76(105)$ & $17(8)$ & 0.90 \\
\hline & $3^{\circ} \mathrm{S}-30^{\circ} \mathrm{S}$ & $3.0(1.8)$ & $80(56)$ & $18(12)$ & 0.90 \\
\hline Ethane & $35^{\circ} \mathrm{N}-8^{\circ} \mathrm{N}$ & $6.0(1.0)$ & $5.5(1.3)$ & $15(8)$ & 0.96 \\
\hline Propane & $35^{\circ} \mathrm{N}-8^{\circ} \mathrm{N}$ & $1.7(0.3)$ & $5.2(1.2)$ & $15(8)$ & 0.91 \\
\hline$n$-Butane & $35^{\circ} \mathrm{N}-8^{\circ} \mathrm{N}$ & $0.8(0.1)$ & $4.2(1.0)$ & $15(8)$ & 0.91 \\
\hline
\end{tabular}

$2 \times 10^{7}$ molec $\mathrm{cm}^{-2} \mathrm{~s}^{-1}$. Only about half of the datapoints showed fluxes significantly different from zero. No systematic trend in the direction of the fluxes with latitude could be established. The average fluxes for all three latitude ranges did not differ significantly from zero (cf. Table II). The average of all acetylene fluxes was $2.0 \times 10^{6} \mathrm{molec} \mathrm{cm}^{-2} \mathrm{~s}^{-1}$ with an error of $0.8 \times 10^{6}$ molec cm $\mathrm{cm}^{-2} \mathrm{~s}^{-1}$ and a standard deviation of $6.4 \times 10^{6} \mathrm{molec} \mathrm{cm}^{-2} \mathrm{~s}^{-1}$.

A comparison of our calculated NMHC emissions with data reported in literature must consider two major sources of uncertainties. Flux calculations are based on NMHC concentrations in sea water which show a large variability. Furthermore, 
different approaches are used in calculating emissions. Rudolph and Ehhalt (1981) calculated local emission rates in the North Atlantic by use of air sea exchange equations and the NMHC concentrations measured by Swinnerton et al. (1974). The resulting figures were $3.6 \times 10^{8}$ molec $\mathrm{cm}^{-2} \mathrm{~s}^{-1}$ for ethene, $2.0 \times 10^{8}$ molec $\mathrm{cm}^{-2} \mathrm{~s}^{-1}$ for propene, $1.7 \times 10^{8}$ molec $\mathrm{cm}^{-2} \mathrm{~s}^{-1}$ for ethane, and $1.5 \times 10^{8}$ molec $\mathrm{cm}^{-2} \mathrm{~s}^{-1}$ for propane. These figures agree within a factor of 2 with our results from the mid-Atlantic (Table II). Bonsang et al. (1988) used a global approach. The oceanic propane emission of $1 \times 10^{-2} \mathrm{gC} \mathrm{m}^{-2} \mathrm{yr}^{-1}$ (Bonsang and Lambert, 1985) was used to scale the emissions of other NMHC according to their relative abundance in sea water. The proposed propane emission of Bonsang and Lambert (1985) corresponds to $5 \times 10^{8}$ molec $\mathrm{cm}^{-2} \mathrm{~s}^{-1}$, a figure of about a factor of eight higher than our value of $0.65 \times 10^{8}$ molec $\mathrm{cm}^{-2} \mathrm{~s}^{-1}$. Additionally, the different ratios of NMHC relative to propane between Bonsang et al. (1988) and our data give rise to differences. The emission rates of Bonsang compared to our results are larger by factors between 4 (ethane) and 20 ( $i$-butane). For the dominantly emitted compounds ethene and propene, they gave figures of $36 \times 10^{8}$ molec $\mathrm{cm}^{-2} \mathrm{~s}^{-1}$ and $18 \times 10^{8}$ molec cm $\mathrm{cm}^{-2} \mathrm{~s}^{-1}$, which are one order of magnitude higher than our values of $3.4 \times 10^{8}$ molec cm $\mathrm{cm}^{-2} \mathrm{~s}^{-1}$ and $1.7 \times 10^{8} \mathrm{molec} \mathrm{cm}^{-2} \mathrm{~s}^{-1}$, respectively.

With a similar approach Kanakidou et al. (1988) estimated the global oceanic source of acetylene by scaling it to the propane emission of Bonsang and Lambert (1985). The resulting figure of $0.2-1.4 \times 10^{12} \mathrm{gC} / \mathrm{yr}$, a value which corresponds to $0.5-3.7 \times 10^{8}$ molec $\mathrm{cm}^{-2} \mathrm{~s}^{-1}$, differs considerably from our result of $(2 \pm 6) \times 10^{6}$ molec $\mathrm{cm}^{-2} \mathrm{~s}^{-1}$.

However, in spite of their global approaches, the emission rates from Bonsang $e t$ al. (1988) and Kanakidou et al. (1988) are based on a relatively small number of measurements in restricted ocean regions. They did not include measurements in open ocean areas remote from islands or continents. Furthermore, these investigations covered only short time periods and, thus, do not include possible seasonal variations of the oceanic NMHC concentrations. Therefore, the substantial differences in the individual emission estimates are not surprising.

\subsection{The Balance of the $C_{2}-C_{4}$ Hydrocarbons in the Surface Water}

Our knowledge about production and destruction processes of light hydrocarbons in the ocean is rather poor. Wilson et al. (1970) reported an increase in light alkene concentrations in sterilized sea-water samples enriched with dissolved organic carbon when exposed to light. No increase in light alkanes was observed. Despite of this most probable photochemical alkene production, they also found enhanced production of hydrocarbons in the presence of the phytoplankton species Chaetoceros galvestonensis. In this case, smaller amounts of alkanes were also produced. The possible relation of hydrocarbon production with light exposure and phytoplankton abundances can also be seen in field experiments. The vertical distribu- 
tions of hydrocarbons in oxygenated sea water show pronounced maxima in the euphotic zone and decreasing concentrations with increasing depth (Swinnerton and Linnenbom, 1967; Linnenbom and Swinnerton, 1970; Brooks and Sackett, 1973; Macdonald, 1976).

For a water column in a well-mixed surface layer, a simple balance equation can be set up:

$$
\mathrm{d} / \mathrm{d} t\left(c_{w} z_{M}\right)=P-D-k_{w} c_{w} .
$$

The temporal change of the hydrocarbon concentration $c_{w}$ in the mixed layer of the ocean of depth $z_{M}$ is given by the production rate $P$, the destruction rate $D$, and the transfer to the atmosphere $k_{w} c_{w}$ according to Equation (2). We assume a first-order destruction with a rate constant $D_{0}$ :

$$
D=D_{0} c_{w}
$$

and a constant production rate $P$. Assuming steady-state conditions, the hydrocarbon sea-water concentration can then be expressed as a function of the transfer velocity

$$
c_{w^{\prime}}=P /\left(D_{0}+k_{w}\right) \text {. }
$$

We can derive the production rate $P$ and destruction rate constant $D_{0}$ from a leastsquares fit of our sea-water concentrations and the calculated transfer velocities. This was done separately for the latitude ranges $35^{\circ} \mathrm{N}-8^{\circ} \mathrm{N}, 8^{\circ} \mathrm{N}-3^{\circ} \mathrm{S}$, and $3^{\circ} \mathrm{S}-$ $30^{\circ} \mathrm{S}$. The results for ethene and ethane are plotted in Figure 4. The fit parameters for the light alkenes and $n$-alkanes are shown in Table III. The standard deviations of the production and destruction rates are below $c a 50 \%$, except those for propene between $8^{\circ} \mathrm{N}$ and $3^{\circ} \mathrm{S}$ and 1-butene south of $8^{\circ} \mathrm{N}$. The regression coefficients are better than 0.90 , for ethene 0.98 in all latitude ranges. Considering the simple model and the assumption of steady-state conditions, the accuracy of the parameters seems reasonable. In the region between $8^{\circ} \mathrm{N}$ and $3^{\circ} \mathrm{S}$, the model parameters show the poorest fit with 40 to $150 \%$ standard deviations. In this region, the model might be least appropriate since the upwelling might cause inhomogenous conditions in the water.

Ethene, propene, and 1-butene show very similar destruction rate constants within individual latitude ranges. They differ by 10 to $20 \%$ except for differences of a factor 2 in the range between $8^{\circ} \mathrm{N}$ and $3^{\circ} \mathrm{S}$. Between $35^{\circ} \mathrm{N}$ and $8^{\circ} \mathrm{N}$, the averaged transfer velocity of $15 \mathrm{~cm} / \mathrm{h}$ exceeds the destruction rate constant of roughly $10 \mathrm{~cm} / \mathrm{h}$. Here emissions to the atmosphere seem to be the dominant loss process for dissolved alkenes in sea water. In the regions $8^{\circ} \mathrm{N}$ to $3^{\circ} \mathrm{S}$ and $3^{\circ} \mathrm{S}$ to $30^{\circ} \mathrm{S}$, the destruction in sea water is two to five times faster than the emission. The production rate is fairly constant for individual alkenes throughout the three latitude ranges with slightly enhanced values between $8^{\circ} \mathrm{N}$ and $3^{\circ} \mathrm{S}$. This would be consistent with a production mechanism via photodegradation of dissolved organic material possibly released from plankton (Wilson et al., 1970), since the solar irra- 

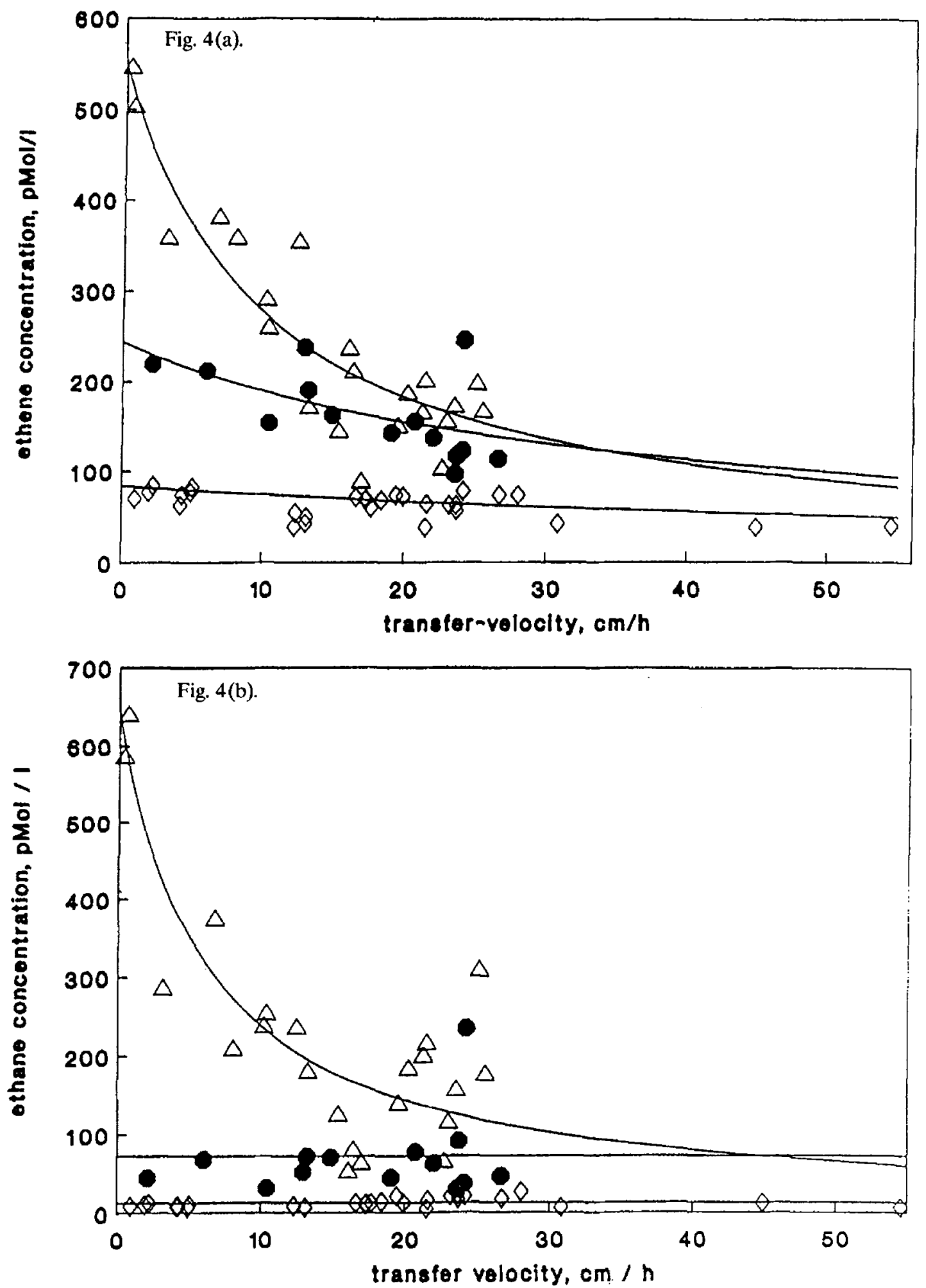

Fig. 4. Sea water concentrations of (a) ethene and (b) ethane as a function of the transfer velocity for the latitude ranges: $35^{\circ} \mathrm{N}$ to $8^{\circ} \mathrm{N}$ (triangles), $8^{\circ} \mathrm{N}$ to $3^{\circ} \mathrm{S}$ (circles), $3^{\circ} \mathrm{S}$ to $30^{\circ} \mathrm{S}$ (diamonds). The solid lines represent the results of the least square fits. 
diation (Hofzumahaus et al., 1992) and the plankton biomass (Harri Kuosa, private communication) did not change between $35^{\circ} \mathrm{N}$ and $30^{\circ} \mathrm{S}$ by more than a factor of two. Just in the range from $8^{\circ} \mathrm{N}$ to $3^{\circ} \mathrm{S}$, the irradiation was reduced due to cloud coverage and the plankton concentration was slightly enhanced possibly related to the equatorial upwelling. However, our data do not enable us to decide, which production processes are involved. The production rates of ethene exceed those of propene and 1-butene by factors of 2 and 3.5, respectively, when only the regions $35^{\circ} \mathrm{N}-8^{\circ} \mathrm{N}$ and $3^{\circ} \mathrm{S}-30^{\circ} \mathrm{S}$ are considered. Thus, the concentration ratios between alkenes (see above) seem to be due to different production rates.

For different alkanes in the region between $35^{\circ} \mathrm{N}$ and $8^{\circ} \mathrm{N}$ the model results in destruction rate constants between 4.2 and $5.5 \mathrm{~cm} / \mathrm{h}$ with standard deviations of less than $25 \%$. Again the dominant loss process seems to be the emission to the atmosphere. The production rates range from $6.0 \times 10^{8} \mathrm{molec} \mathrm{cm}^{-2} \mathrm{~s}^{-1}$ for ethane to $0.8 \times 10^{8}$ molec $\mathrm{cm}^{-2} \mathrm{~s}^{-1}$ for $n$-butane with accuracies better than $20 \%$. In the latitude ranges south of $8^{\circ} \mathrm{N}$, the results indicate constant ratios of production and destruction with a neglectable influence of emissions to the atmosphere. No quantitative estimates for the production and destruction rates can be derived here from this simple model.

Assuming, that the production and destruction take place in a mixed layer of $100 \mathrm{~m}$ depth, we can estimate turnover times for the hydrocarbons from their production rates and their sea-water concentrations. This results in 19,8 , and 4 days for ethene in the latitude ranges $35^{\circ} \mathrm{N}$ to $8^{\circ} \mathrm{N}, 8^{\circ} \mathrm{N}$ to $3^{\circ} \mathrm{S}$, and $3^{\circ} \mathrm{S}$ to $30^{\circ} \mathrm{S}$, respectively. For ethane between $35^{\circ} \mathrm{N}$ and $8^{\circ} \mathrm{N}$, the calculated turnover time is 26 days.

\section{Conclusion}

The Atlantic is supersaturated for $\mathrm{C}_{2}-\mathrm{C}_{4}$ alkenes and alkanes and thus acts as an NMHC source in the marine atmosphere. For acetylene, no significant emissions were observed since both over and undersaturation of acetylene in water with respect to the atmosphere were found. The oceanic hydrocarbon concentration and the fluxes into the atmosphere decrease with increasing molecular weight and alkenes dominate the alkanes. The alkene concentrations are well correlated with each other and the concentration ratios are generally constant in the different ocean areas. The same observation can be made for the alkanes, but between alkenes and alkanes the correlation is not as good and the alkene/alkane ratios vary substantially. This has consequences for estimates of the oceanic NMHC emission rates based on the relative oceanic NMHC concentrations. It seems to be justified to calculate alkane fluxes by scaling the alkane emissions to another alkane, or the same for alkenes. However, any estimate of alkene emissions by comparison with an alkane or, vice-versa, may have very large uncertainties.

Simple budget estimates for three different latitude ranges allow a phenomenological description of the sea-water hydrocarbon concentrations based on three 
simple parameters, production and destruction in the mixed layer of the ocean and emission to the atmosphere. Although this does not yet allow any inference about the nature of the oceanic hydrocarbon production and destruction mechanism, it is very helpful to characterize the different ocean areas with respect to the dominant hydrocarbon removal procedure (emission into the air compared to destruction in the sea water).

The hydrocarbon emission rates for the low primary productive mid-Atlantic range from around $10^{8}$ molec $\mathrm{cm}^{-2} \mathrm{~s}^{-1}$ for alkenes and ethane to less than $10^{7}$ molec $\mathrm{cm}^{-2} \mathrm{~s}^{-1}$ for the $\mathrm{C}_{4}$ alkanes in individual ocean regions. From our observations, we can conclude that processes differ, which determine the oceanic hydrocarbon concentrations, and thus partly also the emission rates. Therefore any global extrapolation might be premature. Still, our data indicate that, in the Atlantic, there seems to be a substantial, and probably systematic, difference in the hydrocarbon concentrations between northern and southern latitudes.

\section{References}

Bonsang, B. and Lambert, G., 1985, Nonmethane hydrocarbons in an oceanic atmosphere, J. Atmos. Chem. 2, 257-271.

Bonsang, B., Kanakidou, M., Lambert, G., and Monfray, P., 1988, The marine source of $\mathrm{C}_{2}-\mathrm{C}_{6}$ aliphatic hydrocarbons, J. Atmos. Chem. 6, 3-20.

Brooks, J. E. and Sackett, W. M., 1973, Sources, sinks, and concentrations of light hydrocarbons in the Gulf of Mexico, J. Geophys. Res. 78, 5248-5258.

Frank, D. J., Sackett, W., Hall, R., and Fredericks, A., 1970, Methane, ethane, and propane concentrations in the Gulf of Mexico, Amer. Assoc. Petrol. Geol. Bull. 54 (10), 1933-1938.

Hofzumahaus, A., Brauers, T., Platt, U., and Callies, J., 1992, Latitudinal variation of measured $\mathrm{O}_{3}$ photolysis frequencies $J\left(\mathrm{O}^{\prime} \mathrm{D}\right)$ and primary $\mathrm{OH}$ production rates over the Atlantic Ocean between $50^{\circ} \mathrm{N}$ and $30^{\circ} \mathrm{S}, \mathrm{J}$. Atmos. Chem. 15, 283-298 (this issue).

Jähne, B., 1980, Zur Parameterisierung des Gastaustausches mit Hilfe von Laborexperimenten, Doctoral dissertation, University of Heidelberg.

Kanakidou, M., Bonsang, B., Le Roully, J. C., Lambert, G., Martin, D., and Sennequier, G., 1988, Marine source of atmospheric acetylene, Nature 333, $51-52$.

Koppmann, R., Bauer, R., Johnen, F. J., Plass, C., and Rudolph, J., 1992, The distribution of light nonmethane hydrocarbons over the mid-Atlantic: results of the Polarstern cruise ANT VII $1, J$. Atmos. Chem. 15, 215-234 (this issue).

Lamontagne, R. A., Swinnerton, J. W., and Linnenbom, W. J., 1974, C $1-C_{4}$ hydrocarbons in the North and South Pacific, Tellus 26, 71-77. 
Linnenbom, V. J. and Swinnerton, J. W., 1970, Low molecular weight hydrocarbons and carbon monoxide in sea water, in Hood (eds.), Organic Matter in Natural Waters, University of Alaska Press, Fairbanks, pp. 455-467.

Liss, P. S. and Merlivat, L., 1986, Air-sea exchange rates: Introduction and synthesis, in Buat-Menard (eds.), The Role of Air-Sea Exchange in Geochemical Cycling, D. Reidel, Dordrecht, pp. 113-127.

Macdonald, R. W., 1976, Distribution of low molecular weight hydrocarbons in Southern Beaufort Sea, Environ. Sci. Technol 10, 1241-1246.

McAuliffe, C., 1966, Solubility of paraffin, cycloparaffin, olefin, acetylene, cycloolefin, and aromatic hydrocarbons, J. Phys. Chem. 70, 1267-1275.

Penkett, S. A., 1982, Non-methane organics in the remote troposphere, in Goldberg (ed.), Atmospheric Chemistry, Springer-Verlag, Berlin, Heidelberg, New York, pp. 329-355.

Platt, U., Rudolph, J., Brauers, T., and Harris, G., 1992, Atmospheric measurements during Polarstern cruise ANT VII $/ 1,54^{\circ} \mathrm{N}$ to $32^{\circ} \mathrm{S}$ : an overview, J. Atmos. Chem. 15, 203-214 (this issue).

Rudolph, J. and Ehhalt, D. H., 1981, Measurements of $C_{2}-C_{5}$ hydrocarbons over the North Atlantic, $J$. Geophys. Res. 86, 11,959-11,964.

Rudolph, J., Johnen, F. J., Khedim, A., and Pilwat, G., 1990, The use of automated 'on line' gaschromatography for the monitoring of organic trace gases in the atmosphere at low levels, Int. J. Environ. Anal. Chem. 38, 143-155.

Sverdrup, H. U., Johnson, M. W., and Fleming, R. H., 1942, The Oceans: Their Physics, Chemistry and General Biology, Prentice-Hall, Englewood Cliffs.

Swinnerton, J. W. and Lamontagne, R. A., 1974, The oceanic distribution of low-molecular-weight hydrocarbons, Environ. Sci. Technol. 8, 657-663.

Swinnerton, J. W. and Linnenbom, V. J., 1967 , Determination of $C_{1}$ to $C_{4}$ hydrocarbons in sea water by gas chromatography, J. Gas Chromatogr. 5, 570-573.

Wilhelm, E., Battino, R., and Wilcock, R. J, 1977, Low-pressure solubility of gases in liquid water, Chem. Rev. 77, 219-262.

Wilson, D. F., Swinnerton, J. W., and Lamontagne, R. A., 1970, Production of carbon monoxide and gaseous hydrocarbons in sea water: relation to dissolved organic carbon, Science 168, 1577-1579. 